This item was submitted to Loughborough's Research Repository by the author.

Items in Figshare are protected by copyright, with all rights reserved, unless otherwise indicated.

\title{
Gendered performances in a male-dominated subculture: 'girl racers', car modification and the quest for masculinity
}

\section{PLEASE CITE THE PUBLISHED VERSION}

http://dx.doi.org/10.5153/sro.2123

\section{PUBLISHER}

University of Surrey, the University of Stirling, the British Sociological Association and SAGE Publications Ltd. (c) Sociological Research Online

\section{VERSION}

AM (Accepted Manuscript)

\section{LICENCE}

CC BY-NC-ND 4.0

\section{REPOSITORY RECORD}

Lumsden, Karen. 2019. "Gendered Performances in a Male-dominated Subculture: 'girl Racers', Car Modification and the Quest for Masculinity”. figshare. https://hdl.handle.net/2134/11668. 
This item was submitted to Loughborough's Institutional Repository (https://dspace.lboro.ac.uk/) by the author and is made available under the following Creative Commons Licence conditions.

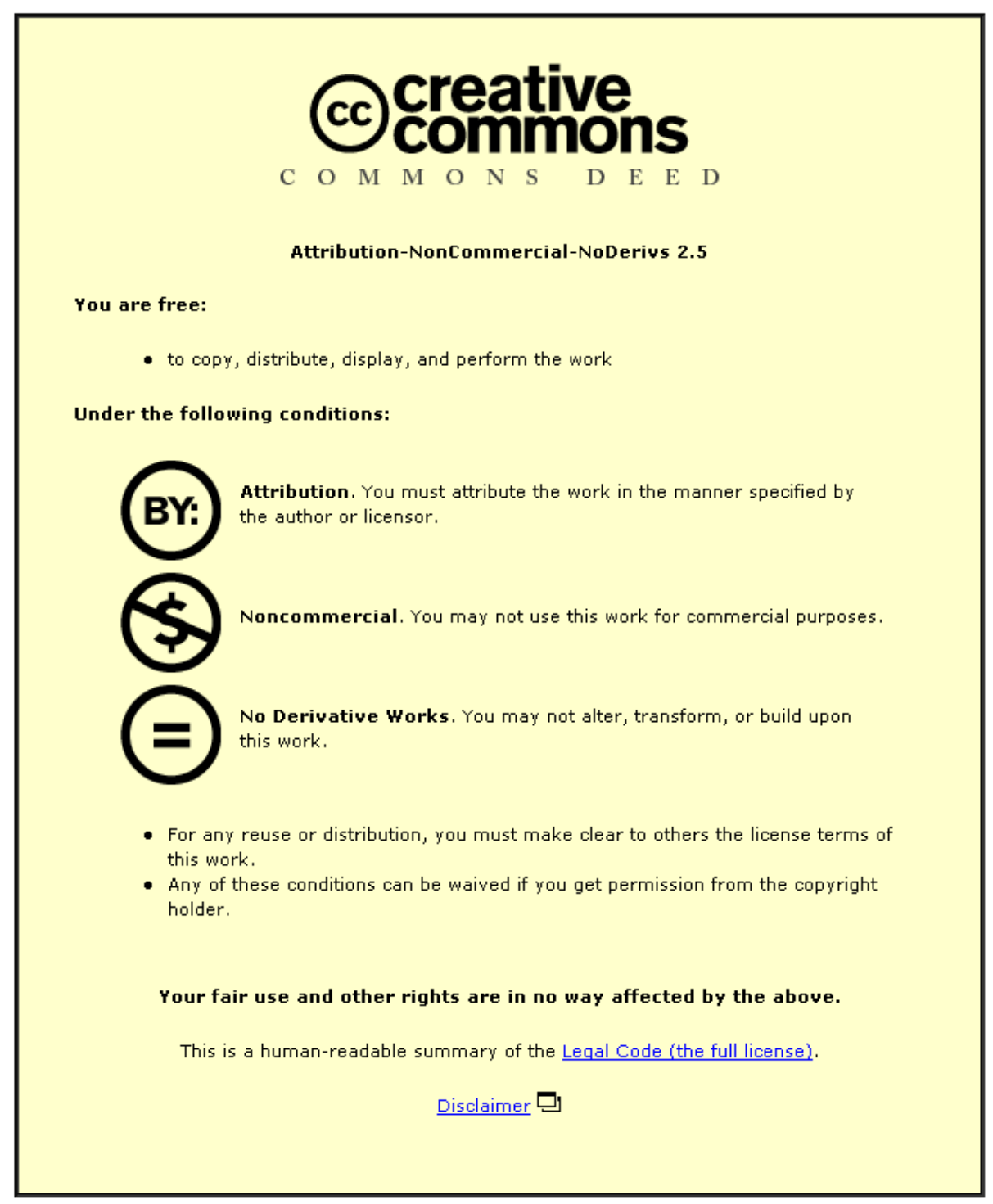

For the full text of this licence, please go to: http://creativecommons.org/licenses/by-nc-nd/2.5/ 


\section{Gendered Performances in a Male-Dominated Subculture: 'Girl Racers', Car Modification and the Quest for Masculinity}

\section{Introduction}

Little is known about girls who join male-dominated subcultures and girls who do participate in youth cultures have traditionally been described as 'passive, ancillary, sexual and "less resistant" than their male peers' (Leblanc, 2006: 67). Studies of car cultures have also tended to describe girls who are present as peripheral participants and emphasise the link between cars and masculinity and male sexuality. Thus, while the triumph and hegemony of the maleness of the car is well known, the agency of gender within this process has been poorly documented (O’Connell, 1998). However, girls are no longer restricted by family and domestic life or excluded from public spaces and a growing number of females now participate in subcultures (Macdonald, 2001). Many young women in contemporary society are exhibiting what have typically been seen as masculine attributes - they are less emotional, more willing to take risks, and seek excitement in certain activities (Wilkinson, 1994). Boys who join subcultures are reasserting their masculinity as the norms and codes of such subcultures are said to 'buttress' masculinity (Leblanc, 2006: 101). On the other hand, girls who join subcultures 'must engage with the discrepancies between subcultural masculinity and mainstream adolescent femininity. The timing of girls' entry... is a clear indication that subcultural participation is an aspect of resistance to gender roles' (Leblanc, 2006: 101).

This paper contributes to studies of youth culture and car cultures by providing an analysis of female participation within the male-dominated 'boy racer' culture. Known in the United Kingdom as 'boy racer' culture, the image of a young male driving a modified car with a spoiler, alloys, lowered suspension, and a loud exhaust and stereo system has permeated the public's imagination. As a collective cultural practice, the 'cruising scene' developed out of unauthorised cultural gatherings of young people in modified cars, that occurred in retail parks and industrial estates late at night during the 1990s (Bengry-Howell, 2005). On occasion these spaces are home to illegal activities such as speeding and street racing. Hence, these gatherings have been presented as a social problem by the authorities and the media (see Lumsden, 
2009a). This discussion focuses on the 'racer' culture in the city of Aberdeen, Scotland. It draws upon data collected from participant observation with the 'racer' culture, semi-structured and ethnographic interviews with participants, and semistructured interviews with members of 'outside' groups.

In the discussion that follows, gender is understood as 'performative' (Butler, 1990, 2004). Hence the 'girl' and 'boy racers' can be seen to be 'doing' gender. The analysis is also framed by Connell's $(1987,1995)$ notions of 'hegemonic masculinity' and 'emphasized femininity'. For the 'girl racers', 'doing' gender involved negotiating a complex set of norms while reconciling the competing discourses of the masculine 'racer' scene and femininity (see Leblanc, 2006). In order to become accepted into the group, the 'girl racers' were required to uphold the masculine doctrine of the culture.

The paper begins by outlining existing studies of car culture and the position of gender within these analyses. It then proceeds to outline the methods adopted in this study of 'racer' culture. The remainder of the paper is concerned with 'girl racers" negotiations of gender roles within a male-dominated subculture. After outlining the masculine nature of the culture, I describe the 'girl racers'" adoption of this masculine doctrine. Their attempts to create space for themselves within this culture through the rituals of car modification and driving are outlined, as is their perception of other females whose participation (as girlfriends, passengers, spectators, 'bikini girls' or 'babes') is delegitimized by the 'girl racers'. Crucially, in the discussion which follows, 'real' participation is understood in terms of females' active involvement in the subculture via their position in the 'driver's seat' in contrast to the role of passenger, girlfriend, or spectator.

\section{Car Culture and the Role of Gender}

In contemporary Western society car cultures are an increasingly popular leisure pursuit amongst adolescents. A hitherto neglected area of academic curiosity and scrutiny, the 'racer' culture in particular and car culture more generally, have recently received increased attention within the social sciences, criminology, cultural studies, geography and urban studies respectively (see Miller, 2001; Redshaw, 2008). 
Research in Australia and New Zealand has highlighted the link between workingclass masculinity and participation in car culture via activities such as car theft, joyriding, road rage and 'racer' culture (see White, 1990; Leigh, 1995; Walker, 1998; Walker et al. 2000; Dawes, 2002; Roberts and Indermaur, 2005; O'Connor and Kelly, 2006; Falconer and Kingham, 2007). Within the United States, researchers have documented the phenomenon of Chicano Lowriders (Allard-Holtz, 1975; Beck, 1980; Vigil, 1991; Bright, 1998) and more recently, Best (2006) has drawn our attention to the 'cruisin', culture in California. The regulation of youth driving practices and street racing has also been a focus of discussion in Canada (Tilleczek, 2004; Vingilis and Smart, 2009) and within Europe studies have included the raggare of Sweden (O'Dell, 2001), the kortteliralli racers of Helsinki (Vaaranen and Wieloch, 2002; Vaaranen, 2004), and the 'boy racer' or car modification scene in the United Kingdom (Bengry-Howell, 2005; Bengry-Howell and Griffin, 2007; Hatton, 2007; Lumsden, 2009b), along with criminological analyses of joyriding and car theft (Campbell, 1993; Stanley, 1995; Groombridge, 1998; Presdee, 2000). Research has highlighted the influence of the crisis of masculinity on members of the 'racer' culture. Hatton (2007) notes that for young men who are unable to find paid employment, or are in low paid jobs, cars and car-related practices are one means through which they can display their masculinity. For 'boy racers', cars help to establish and (re)negotiate hierarchies of power and status (Falconer and Kingham, 2007). Hence the public performances engaged in by 'boy racers' can be seen as crucial rituals through which they construct masculine identities.

Despite the proliferation of studies focusing on car cultures, the role of women within these subcultures remains largely undocumented. Just as the history of the car is gendered, so too are accounts of participation in various forms of car culture which emphasise its relationship with men and masculinity (Bengry-Howell and Griffin, 2007). Until recently, researchers have generally overlooked the role of women within subcultures. However, changes in the gender patterning of young people's leisure pursuits, use of public space, and risk-taking have resulted in the lifting of constraints of respectability on young women's lifestyles (Sweeting and West, 2003). Studies of car cultures offer brief glimpses of female participants and, as Best (2006: 58) notes, although young men dominate the scene, young women play important supporting roles, 
Hardly invisible as they often are in other male-dominated cultural scenes, young women exist under a spotlight of peering eyes, cast as objects whose bodies are inspected as much as the body of a car would be. American car cultures' very organization depends on young women's presence as sexual objects in that they affirm a heterosexual world of masculine competition and bravado; their existence helps to define their opposite, the subjects of this world, young men, as men.

Females who are present in car cultures are often viewed as peripheral participants or as being 'out of place' (see O'Dell, 2001). The marginal roles accommodated by those present include girlfriends of the young men or passengers in their cars (see Bengry-Howell and Griffin, 2007). In contrast, Falconer and Kingham (2007: 185) found that although males tended to predominate, 'the very presence of females in noticeable numbers contradicted a key stereotype associated with the subculture signified in the pervading label "boy racer". Although males were generally the drivers and females the passengers this was not always the case and the female drivers were just as likely to challenge the males for social dominance.

The aim of this paper is to present findings relating to female participation in the male-dominated 'racer' culture in Aberdeen, Scotland. Research highlighted a number of female participants who played active roles in the culture via their positioning in the 'driver's seat', as opposed to merely being peripheral participants.

In this paper, gender is understood as 'performative'. Hence the 'girl' and 'boy racers' can be seen to be 'doing' gender. As Butler (1990: 22) writes,

Gender is a complexity whose totality is permanently deferred, never fully what it is at any given juncture in time. An open coalition, then, will reaffirm identities that are alternatively instituted and relinquished according to the purposes at hand; it will be an open assemblage that permits of multiple convergences and divergences without obedience to a normative telos of definitional closure. 
Additionally, gender identity is seen to be 'socially instituted' and maintained via 'norms of intelligibility' (Butler, 1990: 23). 'Intelligible' genders are those that maintain relations of continuity in contrast to discontinuity and incoherence. Moreover, Butler (1990) refers to the 'strategies' - 'situations of duress' - under which gender performance occurs. This allows us to account for the 'punitive' consequences of particular gendered performances in specific social settings, relations or cultures. In this sense, gender is not understood as a stable identity or 'locus of agency' from which other acts must follow. For Butler (1990: 191, original emphasis), 'gender is an identity tenuously constituted in time, instituted in an exterior space through a stylized repetition of acts'.

This paper also draws upon Connell's (1987, 1995) notions of 'hegemonic masculinity' and 'emphasized femininity'. Hegemonic masculinity is centrally connected with the institutionalization of men's dominance over women and is hegemonic through its embodiment of a successful strategy in relation to women (Carrigan et al. 1985). This provides the basis for relationships among men that define a hegemonic form of masculinity. No femininity is hegemonic in the same way as hegemonic masculinity is amongst men however the global subordination of women to men provides the basis for a differentiation of femininities. Connell identifies three forms of femininity. Emphasized femininity is defined around compliance with the subordination of women and thus is structured to accommodate the interests and desires of men. The second form of femininity is defined around strategies of resistance against the subordination of women by men. The third type is a mixture of the first two and is thus defined by 'complex strategic combinations of compliance, resistance and cooperation' (Connell, 1987: 184). This paper will argue that 'girl racers' resourcefully negotiated their way through the world of 'boy racers' by employing complex combinations of compliance, resistance and cooperation with the masculine values of the group. Moreover, their resistance to this masculinity was restricted for in doing so they risked being excluded as authentic members of the subculture. Before discussing this, the next section will outline the methods adopted in this study. 


\section{The Study}

The city of Aberdeen, Scotland formed the setting for doctoral research into the 'racer' culture from September 2005 to September 2008. Access to the culture was aided by Grampian Police who regularly met with a group of young drivers. The police officer that organized these meetings introduced me to Debbie, the main representative from the Drivers' Group, who became my initial gatekeeper. The research employed ethnographic methods, which allowed an in-depth look at the everyday lives of its members, the reasons, feelings, and justifications for their actions, and for their participation in the culture. In total 150 hours were spent with the group from September 2006 to August 2007. The role of overt participant observer was adopted. During the fieldwork period I spent weekend evenings in the main setting - Aberdeen Beach. In total 100 hours were spent with the group at Aberdeen's seafront. The fieldwork also included attending Drivers' Group meetings every three months. I attended four meetings between 2006 and 2007 which accounted for ten hours in the field. I also attended two car shows in Aberdeen, an Italian car show in St Andrews and four meetings (referred to as 'meets' or 'cruises') in various locations across Scotland. The fieldwork also involved socialising with members of the group to celebrate events such as birthdays, as well as accompanying them to scrap yards, car auctions, garages and shops to search for car parts and accessories.

In terms of participation, I was able to engage with the group as a fellow 'driver' through the fact that I owned a Fiat Punto. This granted me access to an additional area of the culture and a second gatekeeper, Robert, who ran a website centred on Fiats. For Robert, my car became the focus of a project to clean it up and improve its appearance with various proposed modifications. At the beginning of the research, whether I would be accepted into the group since my car had not been modified was a cause for concern. Showing appreciation and admiration for others' cars was vital to becoming accepted as one of the group. Furthermore, agreeing with the group that certain cars were not tastefully 'modified' also helped to gain their acceptance. Robert's efforts to have me fully participate in the culture via car modification can be viewed as evidence of my acceptance into the group in terms of participation as a 'driver' or potential 'girl racer'. 
Data collection also consisted of semi-structured interviews with eight members of the culture (and one former member), which were recorded and transcribed. Debbie was the only female who was willing to participate in a formal interview, and (with the exception of Debbie) all respondents were aged between 20 and 25 years old. Members of the outside groups who voiced concern about the 'racer' culture also participated in semi-structured interviews. Interviews were conducted with four police officers, a local councillor, a Member of Parliament, a Member of the Scottish Parliament, three journalists and two local residents. A focus group was also conducted with four residents present. Data collection also included ethnographic interviews with members of the subculture throughout the duration of the fieldwork. These ethnographic interviews took the form of casual or informal chats. The following sections present findings which focus on the role of gender within the 'racer' culture.

\section{Female Participation in the Male-Dominated 'Racer' Culture}

\section{'Girl Racers': A Threat to Masculinity}

The 'racer' culture in Aberdeen was male-dominated and, as Leblanc (2006: 107) notes,

...the numerical dominance of males in these subcultures is only the tip of the iceberg - these subcultures are indeed specifically constructed to be hypermasculine in order to compensate for perceived challenges to working-class boys' masculinity in mainstream culture.

For 'boy racers', participation in the car modification scene provided a space in which to construct a form of hegemonic masculinity. Male participants established the 'rules of engagement' and thus defined the behaviours, styles and practices which denote subcultural 'authenticity' (Leblanc, 2006: 109). Female members of the group who were active participants were required to adopt the masculine traits of the culture. To be accepted as authentic participants the 'girl racers' were required to adopt characteristics of the hegemonic 'boy racer' such as toughness, bravado, competitiveness, aggression, the use of crude language, a particular style of dress, 
driving abilities and knowledge of car modification. Sexist treatment and sexual hustling were common and were a means by which the boys could attempt to resist and discredit female participation in the culture. Aggression, sometimes violent, and sex which is sometimes presented in a way that objectifies and humiliates women, are still commonplace in the culture of young men (O'Donnell and Sharpe, 2000). For boys, subcultures are a 'fitting test of their masculinity, and they will emphasise this in crude sexist discussion about women and sex, and also in their parody of homosexual men' (Brake, 1985: 164). Thus, within a male-dominated subculture, 'It is in the boys' interests to nudge her out because, as a girl, she has the power to dilute his masculinity. It is either her or his male credibility - one of them has to go' (Macdonald, 2001: 150). The boys' rejection of females as legitimate or authentic members of the culture through viewing them in sexual terms was one way of dealing with their ambiguous status. In doing so, the boys were able to shift the attention away from the girls' achievements and the challenges this presented to the masculine nature of the subculture.

The 'boy racers' also subordinated male participants who were not working-class and were conceived of as more effeminate. Their attitudes to gender were closely linked to social class. Male participants, who drove sports cars such as Porsches or Ferraris were called 'mummy's boys' and members of the culture assumed that these participants were homosexual. The 'girl racers' had similar attitudes towards these drivers. Hence the 'racer' culture in Aberdeen was a site for male youths. The exclusion of women (and certain men) was a way to 'nourish, amplify and salvage notions of masculinity' (Macdonald, 2001: 149; Connell, 1987). These behaviours were a means by which 'boy racers' could reaffirm their hegemonic masculinity. The girls were forced to confront sexist assumptions about their abilities to drive competently or their knowledge of cars and car modification (see Kelly et al. 2005). However, as we shall see, this internal form of oppression by the boys is one which the 'girl racers' chose to accommodate rather than resist (Leblanc, 2006).

\section{Becoming a 'Girl Racer'}

Debbie was my preliminary gatekeeper into the 'racer' culture. As the representative at Drivers' Group meetings and the host of a car modification website, Debbie played 
a significant role in the culture. She regularly attended gatherings at Aberdeen's seafront, car shows across Scotland, and organised a car show in Aberdeen on behalf of her website and the Drivers' Group. Debbie was in her early thirties, married and had four children. She had regularly participated in the culture for eight years, owned a Seat Ibiza which she and her husband had modified together, and often spoke of her love for cars and car modification. She also had a passion for off-road racing and regularly attended events across Scotland in her pink Suzuki Vitara. Debbie was far from the stereotypical image of a 'boy' or 'girl racer', a fact she was aware of. Other drivers at Aberdeen Beach believed that she did not belong in the culture because of her age. Debbie informed me:

People do comment on why older people like me go down here but then why shouldn't I? Age shouldn't make a difference when you're interested in cars. When my children were little we would take them along with us in the summer and they would play on the grass beside the car. If people question why we would do that then well it's not as bad as going out on a Saturday night clubbing and getting drunk while leaving your kids at home. All my kids have shown some sort of interest in cars. Like the youngest who is two thinks that you can fix dents in cars with hammers! My six year old daughter also spends time under a car helping her dad and my other two sons who are older also show an interest, unless it involves helping out (Fieldnotes, September 2006)

Historically, women have been functionally positioned in the passenger seat of cars rather than in the driver's seat and the car itself is entangled in 'a web of meaning spun with the threads of masculinity and femininity' (Scharff, 1991: 40). The role of 'girl racer' can be seen to challenge this functional ranking. Female participants such as Debbie positioned themselves as fully active members of the culture through their participation at car shows and events, on website forums, through knowledge and modification of their cars and their presence at Aberdeen's Beach Boulevard. They were owners and drivers of cars, not merely passengers or spectators. When asked 'why is your car important to you?' Debbie likened car modification to any other hobby or leisure activity: 
I could answer that by asking 'well why is granny's knitting important to her, or your mum's bingo, or meeting for a cup of tea?' It's important because it's a hobby. It's a love for cars and engines and most people have grown up with this in their blood, watching their dads or uncles working on cars and so they have an interest in it. That's also why I wouldn't be stupid and risk losing my license or totalling my car by driving like an idiot. I've put so much time and money into it. I don't want to wreck it and I need it for everyday. Losing my licence would change my entire life.

Debbie drew from her individual biography to explain her participation. She spoke of the enthusiasm she had for cars at an early age and the curiosity that this entailed. Participation in the 'racer' culture was seen as natural, inevitable and pre-determined by her socialization (see Bourdieu, 1990). She informed me that more girls were now participating in the 'racer' culture:

Interviewer: Do a lot of girls participate in the culture?

Debbie: There are a lot more girls participating. When the group started you would have girls as just passengers and maybe the odd few drivers but it was rare. Now there's probably the same amount of boys and girls. It's not just the boys that want to pass their test and own a car as soon as they can, girls do too and why shouldn't they? Girls can be interested in cars...

Hence, where traditionally girls would have been more likely to participate as girlfriends or passengers, female drivers were now more common. Debbie also acknowledges that traditionally the subculture was male-dominated and that interest and enthusiasm for cars was viewed as a masculine trait. For Debbie, the subculture provided freedom from the predictability of family life and the car provided a means through which to socialize with like-minded car enthusiasts. She positioned herself against an emphasized femininity through her participation in the male-dominated world of 'boy racers' (see Currie et al. 2006). 
Although they identified themselves as car modifiers or enthusiasts, the girls did not view themselves as 'racers'. Participants viewed the labels of 'boy' or 'girl racer' negatively (Lumsden, 2009a). The 'racer' label as well as being representative of deviant driving and anti-social behaviour was viewed in masculine terms. As Falconer (2004) notes, the term 'boy racer' has come to signify male, adolescent selfishness and hedonism. However, the girls were required to embrace the masculine norms of the culture in order to be accepted. The masculine behaviours of the 'racer' culture were inherent to its definition by the mainstream thus participation in the subculture for girls, meant an unavoidable association with this masculinity (Leblanc, 2006).

\section{Performing Gender: Car Modification and Trials by Speed}

Car modification was a central ritual of the culture and the 'girl racers' were as enthusiastic and knowledgeable about their cars as the boys. For Paul, a girl's interest in car modification and participation in the culture was 'understandable because it's like they spend money on clothes and make-up to look good, so why not their cars too? There are a number of girl racers there who are just as keen about their cars as the boys are'. Hence for Paul, female participation in the car culture is related to their tendency to buy products from the beauty and fashion industries and the 'need to look good' extends to their cars. He thus understands car modification by girls as related to the practices of emphasized femininity. However, the 'girl racers' invested their time and money on modifications such as stereo systems, body kits and exhausts:

Interviewer: Why do you think people enjoy modifying their cars?

Debbie: It's because they're interested in cars and they want to make theirs look different from everyone else. My car is different from other Ibizas - it's individual. It's how I want it to look and there's a reward when you do all the work yourself and invest lots of time and money into it. And nowadays, a car is the next most expensive item after a house and lots of people own a car before a house. It's the first thing that most people buy which costs more than $£ 200$. 
Debbie comments on the importance of modifying a car to make it look different from other mass-produced cars, in this case, other Seat Ibizas, and to do so in a way which reflects her own personal taste. She also highlights the importance of modifying the car herself. For 'girl racers', the time, effort and money invested in modifying a particular vehicle make the experience worthwhile and rewarding. The purpose of car modification is to elicit a reaction from bystanders and gain appreciation and admiration for the work done on their cars. Thus, for both 'boy' and 'girl racers', having an impressive vehicle to drive around in and show off at social events can be a source of pride and self-esteem. Debbie acknowledges the importance of people appreciating her cars:

Interviewer: $\begin{aligned} & \text { What modifications have you made to your car? } \\ & \text { Debbie: }\end{aligned}$
I have three cars at the moment. This one, the Ibiza, is my
everyday car. I've spent more money modifying it than I
did buying the car. I've put in a sound system, lowered it,
new body kit, alloys, wheels, exhaust. They're
modifications that I like. They might not be to everyone
else's taste. I have a Subaru Impreza that will eventually
replace this one as my everyday car. The Ibiza some
people would appreciate at a show cos it looks good and
you can see the modifications. The Impreza they'd
appreciate for the engine size and horsepower, and I have
the four-by-four, which some people might appreciate for
being different.

Female participants also attempted to bring elements of femininity into the culture through the modification of their cars. In their study of the street racers of Helsinki, Vaaranen and Wieloch (2002: 45) refer to the 'Volvo girls', street racing women who 'bring careful driving to the streets, and traditional home-values to the decoration of cars, as expressed by teddy bears, pillows and tidiness'. One of the most common ways of adding a feminine touch to their car was to re-spray it a shade of pink. For instance Vicky arranged to have her Ford Fiesta re-sprayed a shade of pink in preparation for a local car show. Debbie also drove a pink Suzuki Vitara which was her 'pride and joy'. She said 'When I'm driving in town I forget what colour it is until 
I notice people pointing at it and remarking on the colour'. As Atkinson (2002: 224) notes, acts of conformity and resistance to social edict are 'inexorably intertwined'. Although the female modifiers attempted to resist their traditional feminine roles by participating in a male-dominated culture, this was reproduced through rituals such as car modification and their wider adoption of the culture's masculine norms. Thus:

Even though these projects tend to be whitewashed with nouveau-hip sentimentalities about 'girl power' and the freedom of choice (vis-à-vis the dismantling of established gender codes), they almost invariably reproduce established ideas about femininity and the feminine body (Atkinson, 2002: 225-26, original emphasis).

Moreover, although the 'girl racers' consciously positioned themselves against an emphasized femininity through their participation in car culture, they retained an element of this through the ways in which they chose to modify their cars. They expanded the meaning of femininity by using the resources of the male-dominated culture to make those norms and values their own (Kelly et al. 2005).

Although they added feminine touches to their cars, the modifications they carried out, the language they used, their style of dress, and actions approximated to the masculine values of the culture. The 'racer' culture in Aberdeen can be viewed as a space in which girls can explore their feminine identity. However, the extent to which they could do so was restricted and they were contained within this male-dominated culture. They were required to embrace the culture's masculine norms (Kelly et al. 2005). In male-dominated cultures such as the 'racer' culture, the boys set the yardstick against which the girls are judged (Fine, 1987). Status within the group was defined in masculine terms. Debbie showed an awareness of the masculine nature of the culture and the gendering of the car as masculine. She recalled an accident which she believed was the 'girl racer's' fault:

We were parked at the side of the road in a line of cars and it ended up being a four car long pile-up. We were lucky that we weren't in the car at that moment. Instead we were standing on the grass verge beside the car with the kids. The girl was showing off and racing someone off the lights. 
She couldn't control the car going round the bend, lost control and drove into the back of our car. She said she hadn't seen the parked cars and was laughing because she thought it was funny. The boy in the other lane was charged with reckless driving because in court the girl said that he'd boxed her in and all of her friends backed up her story. I didn't think it was very fair (Fieldnotes, September 2006).

Here, Debbie identifies the 'girl racer's' failure to adopt the masculine sign of 'capability' as opposed to the feminine sign of 'incapability' (see Macdonald, 2001: 131) through her dangerous and risky driving. In the 'racer' culture, the females were not passive and subordinate and drove with as much skill and daring as the boys. However, these displays of bravado by females can be seen as a means of adhering to the masculine values of the culture. One local resident claimed that the 'girl racers' were worse than the boys:

Interviewer: Is it mostly boys that race?

May: $\quad$ Oh no there's girls as well. There were girls. Mostly boys but there are girls as well.

William: There's a fair mixture.

May: $\quad$ There are girls as well...some of them are madder than the boys. Do you remember that night when we had our cabin and we took a walk to Fittie for our exercises? We came back from Fittie and we crossed the Boulevard. We had to run to cross both sides. We had to run from this side to the island because of the boys, and the traffic coming up that way, and we had to run across to what is now where the new houses are. We stood and we watched and there was a little car with four young lads in the front and they were going all out down the Boulevard and there was a maroon car, I can see that lassie yet. It was a Triumph something, was the name of it. This was her: she was over the wheel like that, leaning, and she must have had her foot full on the accelerator and the little car, if that had stopped she was right over it. She'd long dark 
hair down to there, practically standing, she wasn't sitting, she was standing over the wheel like this, and she was after this little car. That's the sort of thing that went on there. I said, 'Oh if that little car stops they're all killed, every one of them's killed'. It was four young lads and it was a little wee car and she'd this bigger car and she was actually standing over the wheel...

A local police officer believed there had been an increase in the number of girls taking part in races and speeding:

There are girls as well you know. I'm not being sexist. Over the years I've seen an increase in the number of girls now that are doing exactly the same as the boys - getting themselves into competitions, trials by speed, sitting at lights, revving the engines, lights change to green, they wheel spin away and they try to out accelerate each other. You know, it's a straight bit of road but they don't think about the consequences of what they're doing.

Therefore by challenging the boys and competing with them in street races, the girls attempted to prove themselves as authentic members of the culture. Becoming 'one of the boys' was a means by which the 'girl racers' interactionally managed female gender in this masculine culture. However these 'girl racers' are in a double-bind, for, as Brewer (1991: 240) notes in his study of female police officers in the Royal Ulster Constabulary, 'In order to cope with the masculinity of the occupational culture and be accepted as an equal member of the police, they interactionally underscore their own femininity, only to be rejected as women because they do not conform to the gender role'. Therefore female members of the 'boy racer' culture who act like one of the boys win acceptance as members of the culture, but not as women. They mix aspects of emphasized femininity with an adoption of the masculine values of the group. Hence the female car modifiers are required to employ complex strategies of compliance, resistance and cooperation (Connell, 1987). 
Emphasized Femininity: The Peripheral Participants

The 'girl racers' defined an alternative femininity against other women (see Kelly et al. 2005) who were seen as peripheral participants. This included the 'babes' and 'bikini girls' and the girlfriends or passengers. In many instances, the 'girl racers' were introduced to the culture by accompanying their partner or friend as a passenger in their car. Female participation in the culture by girlfriends or passengers was also seen as the norm. According to Vicky:

Most folk, like me and Debbie, started coming here with our partners. So that's how we became interested in it. Soon as we'd passed our tests and could afford a car we started coming here on our own. It's good not to rely on someone else to drive you everywhere. I think for a lot of the people who come down here they were originally introduced to it through being passengers in friends' cars. It's a good way to get a feel for it first (Fieldnotes, April 2007).

Therefore the girls gained entry into the 'racer' scene through respect which they earned via their adoption of masculine characteristics. Debbie drew attention to those girls who were passengers or girlfriends and not yet part of the subculture as expressing a form of emphasized femininity in order to accommodate the needs of the boys. The passengers and girlfriends emphasized their femininity through the clothes they wore and their actions. According to Debbie:

A lot of people think this is a good place to meet folk or pull someone. You see the girls that come down here with their friends or boyfriend and also those who aren't part of the car modding ${ }^{1}$ scene but choose to drive past to have a look, see what's going on. They can be quite annoying cos you know they aren't here cos they're serious about cars. It's just a case of trying to find a partner. So they'll be quite tarty when you see them sometimes and in your face. They'll think it's funny to toot their car horn and flash their lights at folk to get attention but they don't really know what it's about (Fieldnotes, April 2007). 
Debbie associates this form of participation with incapability since they do not have knowledge of the workings of the subculture. Moreover, this form of emphasized femininity is defined around compliance with subordination by the hegemonic 'boy racer' and is thus oriented to 'accommodating the interests and desires of men' (Connell, 1987: 183). Debbie told me about some of the girlfriends of 'boy racers':

Younger girls will come down to the beach because they think they can easily pull a guy here and especially because they have a car. A lot of the drivers who have girlfriends who are around seventeen years old don't realise that the girl is only with them because of their car, not because of who they are (Fieldnotes, September 2006).

Hence, in order to become accepted as an authentic 'girl racer' by existing participants, the girlfriends and passengers are required to forgo their performances of emphasized femininity in exchange for the masculine doctrine of the culture. Only then can they ensure their position as legitimate subcultural participants. As Leblanc (2006: 32) writes with regards to punk girls: 'They recognise the male domination of the subculture and accept, internalise and project these norms, adopting many of these norms in their own assessments and expectations of other punk girls'.

The other form of peripheral participation which the 'girl racers' defined themselves against included the 'babes' and 'bikini girls' who featured at car shows and in magazines and Internet sites. At events such as the Fast and Modified car shows, men posed to have their photograph taken alongside these models and the cars. Women and their bodies have traditionally been used to sexualise and display the motor car at shows and events. For instance in Formula One these models have been referred to as 'pit babes' or 'Marlboro Girls'. The 'girl racers' viewed this form of participation negatively:

'I mean, have you seen the state of them?' Vicky asked. 'The fake orange tan, bleached blonde hair and hot pants. To be honest they look like sluts to me. Why would you want to stand there at a show and get your picture taken by men? It's sad. And you see some of them in magazines. They 
wouldn't think twice about getting their tits out for a photo' (Fieldnotes, August 2006).

Laura added:

They make us all look bad. We're serious about our cars and when you see them it pisses you off cos it's saying to the guys that women can't be interested in modding. It's like saying all we're good for is being ornaments or something (Fieldnotes, August 2006).

Hence, 'girl racers' showed disdain for the 'babes' or 'bikini girls' who they believed negatively represented female participation in the culture. They believed that models' use of their bodies to sexualise the car threatened their status as legitimate 'girl racers'. These 'bikini girls' and 'babes' were symbolic of the subordination of females within the culture by the hegemonic 'boy racers'. The 'girl racers' positioned themselves against the 'homogenous mainstream' of females who expressed emphasized femininity (Kelly et al. 2005: 236). This was achieved through in-group language, dress style, car modification, and by avoiding behaviour(s) that they associated with the norms of mainstream femininity. Despite this, however, they were still constrained by the male-dominated culture's gender relations (Kelly et al. 2005: 238).

\section{Conclusion}

Participation in car culture allows opportunities for men to demonstrate their knowledge, to stand out and be unique, and feel they have met societal definitions of masculinity. The 'racer' culture in Aberdeen can be seen as a space for the construction of a form of hegemonic masculinity. The culture was aligned with traditional working-class values and thus was traditional in its attitude towards gender. Female members of the culture who wanted to be accepted as genuine 'girl racers' were required to follow this masculine doctrine. This entailed acting like one of the boys through their style of driving, car modification, dress, and language. Hence, the 'girl racers'" negotiations were constrained by the masculine 'racer' culture. They internalised these gender norms rather than resisting them explicitly, for 
fear of being excluded from the subculture (Kelly et al. 2005; Leblanc, 2006). Therefore as Best (2006: 78) argues, 'Girls in this cultural scene move under the specter of a crude masculine power that is ritually expressed and enacted through the physical and symbolic forms that define this scene's very essence'. Although the 'girl racers' did not always agree with the masculine doctrine of the culture, they were required to 'tow the line' in order to ensure their acceptance as authentic participants (Leblanc, 2006: 110).

The 'bikini girls' or 'babes' and the girlfriends or passengers adhered to a form of emphasized femininity through their appeasement of the values and needs of the hegemonic 'boy racers'. For the 'girl racers', these were subordinate forms of participation. Participating as a girlfriend or passenger was a means by which many females could gain entry to the culture before becoming serious 'girl racers'. However, this meant foregoing their performances of emphasized femininity in exchange for the masculine values, characteristics and actions of the 'racer' culture. The feminine ways in which the 'girl racers' modified their cars allowed them to retain an element of femininity in a world of boys. Since the 'racer' culture is also viewed by the mainstream as a masculine culture, by participating in it, and through their displays of driving and styles of car modification, the 'girl racers' also 'subvert the norms of the mainstream culture, the feminine norms of both culture and subculture, and the norms of the...[racer] subculture as well' (Leblanc, 2006: 156). Leblanc (2006: 160) refers to this as a position of 'trebled reflexivity'. The space created by 'girl racers' within this masculine world allows for self-expression and identity work through their cars and car-related practices. Moreover, as Butler (2004: 1) argues,

If gender is a kind of doing, an incessant activity performed, in part, without one's knowing and without one's willing, it is not for that reason automatic or mechanical. On the contrary, it is a practice of improvisation within a scene of constraint. Moreover, one does not 'do' one's gender alone. One is always 'doing' with or for another, even if the other is only imaginary. 
Thus, an investigation into the role of gender within Aberdeen's 'racer' culture illustrates that many females play an active role in subcultures and their rituals. The girls in the male-dominated 'racer' culture were not merely 'boys toys' (Leblanc, 2006: 101), as claimed in previous studies of car culture. They resourcefully negotiated their way through the world of 'boy racers' by employing complex combinations of compliance, resistance and cooperation (see Connell, 1987) with the masculine values of the group. Moreover, their resistance to this masculinity was somewhat restricted, for in doing so, they risked being excluded as authentic members of the subculture. In this paper 'real' participation has been understood in terms of females' active involvement in the subculture via their position in the 'driver's seat' in contrast to the role of passenger, girlfriend, or spectator.

\footnotetext{
${ }^{1}$ Subcultural term used to refer to the process of car modification. It can refer to performance modifications such as engine tuning or aesthetic alterations and customization of the car's body work.
}

\section{References}

ALLARD-HOLTZ, J. (1975) "The "Lowriders": Portrait of an Urban Youth Subculture', Youth \& Society 6(4): 495-512.

ATKINSON, M. (2002) 'Pretty in Ink: Conformity, Resistance and Negotiation in Women's Tattooing', Sex Roles 47(5/6): 219-24.

BECK, P.V. (1980) 'The Low Riders: Folk Art and Emergent Nationalism', Nature Arts/West 1(4): 25-27.

BENGRY-HOWELL, A. (2005) Performative Motorcar Display. Unpublished PhD Thesis: University of Birmingham, UK.

BENGRY-HOWELL, A. and GRIFFIN, C. (2007) 'Self-Made Motormen: The Material Construction of Working-Class Masculine Identities through Car Modification', Journal of Youth Studies 10(4): 439-58.

BEST, A.L. (2006) Fast Cars, Cool Rides. New York: New York University Press. BOURDIEU, P. (1990) The Logic of Practice, trans. R. NICE. Cambridge: Polity. BRAKE, M. (1985) Comparative Youth Culture. London: Routledge \& Kegan Paul. BREWER, J.D. (1991) 'Hercules, Hippolyte and the Amazons - or Policewomen in the RUC', British Journal of Sociology 42(2): 231-47. 
BRIGHT, B. (1998) “"Heart Like a Car”: Hispano/Chicano Culture in Northern New Mexico', American Ethnologist 25(4): 583-609.

BUTLER, J. (1990) Gender Trouble. London: Routledge.

BUTLER, J. (2004) Undoing Gender. London: Routledge.

CAMPBELL, B. (1993) Goliath. London: Methuen.

CARRIGAN, T., CONNELL, B. and LEE, J. (1985) 'Toward a New Sociology of Masculinity', Theory and Society 14(5): 551-604.

CONNELL, R.W. (1987) Gender \& Power. Stanford, CA: Stanford University Press.

CONNELL, R.W. (1995) Masculinities, 2nd edn. Cambridge: Polity Press.

CURRIE, D.H., KELLY, D.M. and POMERANTZ, S. (2006) "“The Geeks Shall Inherit the Earth": Girls' Agency, Subjectivity and Empowerment', Journal of Youth Studies 9(4): 419-36.

DAWES, G. (2002) 'Figure Eights, Spin Outs and Power Slides: Aboriginal and Torres Strait Islander Youth and the Culture of Joyriding', Journal of Youth Studies 5(2): 195-208.

FALCONER, R. (2004) Boy Racer, an Ambiguous Label. Unpublished MSc Thesis: University of Canterbury, New Zealand.

FALCONER, R. and KINGHAM, S. (2007) “"Driving People Crazy”: A Geography of Boy Racers in Christchurch, New Zealand', New Zealand Geographer 63: 181-91. FINE, G. (1987) 'One of the Guys: Women in Male Dominated Settings', in M. KIMMEL (editor) Changing Men. Newbury Park, CA: Sage.

GROOMBRIDGE, N. (1998a) 'Masculinities and Crimes Against the Environment', Theoretical Criminology 2(2): 249-67.

HATTON, Z. (2007) The Tarmac Cowboys. Unpublished PhD Thesis: University of Plymouth, UK.

KELLY, D.M., POMERANTZ, S. and CURRIE, D. (2005) 'Skater Girlhood and Emphasized Femininity: "You Can't Land an Ollie Properly in Heels", Gender and Education 17(3): 229-248.

LEBLANC, L. (2006) Pretty in Punk. London: Rutgers University Press.

LEIGH, A. (1995) 'Youth and Street Racing', Current Issues in Criminal Justice 7(3): 1-8. 
LUMSDEN, K. (2009a) 'Do We Look Like Boy Racers? The Role of the Folk Devil in Contemporary Moral Panics', Sociological Research Online 14(2): $<$ http://www.socresonline.org.uk/14/1/2.html>

LUMSDEN, K. (2009b) Rebels of the Road. Unpublished PhD thesis: University of Aberdeen, UK.

MACDONALD, N. (2001) The Graffiti Subculture. New York: Palgrave Macmillan. MILLER, D. (editor) (2001) Car Cultures. Oxford: Berg.

O'CONNELL, S. (1998) The Car in British Society. Manchester: Manchester University Press.

O'CONNOR, C. and KELLY, K. (2006) 'Auto Theft and Youth Culture: A Nexus of Masculinities, Femininities and Car Culture', Journal of Youth Studies 9(3): 247-67.

O’DELL, T. (2001) 'Raggare and the Panic of Mobility: Modernity and Hybridity in Sweden', in D. MILLER (editor) Car Cultures. Oxford: Berg, pp.105-32.

O'DONNELL, M. and SHARPE, S. (2000) Uncertain Masculinities. London: Routledge.

PRESDEE, M. (2000) Cultural Criminology and the Carnival of Crime. London: Routledge.

REDSHAW, S. (2008) In the Company of Cars. Aldershot: Ashgate.

ROBERTS, L. and INDERMAUR, D. (2005) 'Boys and Road Rage: Driving-Related Violence and Aggression in Western Australia', Australian and New Zealand Journal of Criminology 38(3): 361-80.

SCHARFF, V. (1990) Taking the Wheel: Women and the Coming of the Motor Age. New York: Free Press.

STANLEY, C. (1995) 'Teenage Kicks: Urban Narratives of Dissent Not Deviance', Crime, Law \& Social Change 23(2): 91-119.

SWEETING, H. and WEST, P. (2003) 'Young People's Leisure and Risk-Taking Patterning in the West of Scotland during the 1990s', Journal of Youth Studies 6(4): 391-412.

TILLECZEK, K.C. (2004) 'The Illogic of Youth Driving Culture', Journal of Youth Studies 7(4): 473-98.

VAARANEN, H. (2004) 'The Emotional Experience of Class: Interpreting WorkingClass Kids' Street Racing in Helsinki', The ANNALS of the American Academy of Political and Social Science 595(1): 91-107. 
VAARANEN, H. and WIELOCH, N. (2002) 'Car Crashes and Dead End Careers:

Leisure Pursuits of the Finnish Subculture of the kortteliralli Street Racing', YOUNG: Nordic Journal of Youth Research 10(1): 42-58.

VIGIL, J.D. (1991) 'Car Charros: Cruising and Lowriding in the Barrios of East Los Angeles', Latino Studies Journal 2(2): 71-79.

VINGILIS, E. and SMART, R.G. (2009) 'Street Racing: A Neglected Research Area?' Traffic Injury Prevention 10(2): 148-56.

WALKER, L. (1998) 'Chivalrous Masculinity Among Juvenile Offenders in Western Sydney: A New Perspective on Young Working Class Men and Crime', Current Issues in Criminal Justice 9(3): 279-93.

WALKER, L., BUTLAND, D. and CONNELL, R.W. (2000) 'Boys on the Road: Masculinities, Car Culture and Road Safety Education', Journal of Men's Studies 8(2): 153-69.

WHITE, R. (1990) No Space of their Own. New York: Cambridge University Press. WILKINSON, H. (1994) No Turning Back. London: Demos. 